Check for updates

Cite this: Metallomics, 2019, 11,914

Received 2nd November 2018, Accepted 20th February 2019

DOI: $10.1039 / \mathrm{c} 8 \mathrm{mt} 00317 \mathrm{c}$

rsc.li/metallomics

\section{Lanthanides compete with calcium for binding to cadherins and inhibit cadherin-mediated cell adhesion $\dagger$}

\author{
Lewis L. Brayshaw, (D) ${ }^{a}$ Rosanna C. G. Smith, (D) ${ }^{\text {ab }}$ Magd Badaoui, ${ }^{c}$ James A. Irving ${ }^{\text {c }}$ \\ and Stephen R. Price (D) *a
}

\begin{abstract}
Lanthanides are rare-earth metals with a broad range of applications in biological research and medicine. In addition to their unique magnetic and spectroscopic properties, lanthanides are also effective mimics of calcium and can stimulate or inhibit the function of calcium-binding proteins. Cadherins are a large family of calcium-binding proteins that facilitate cell adhesion and play key roles in embryo development, tissue homeostasis and tumour metastasis. However, whether lanthanides can bind cadherins and functionally replace calcium binding has not been comprehensively explored. In this study, we investigated the effect of lanthanide binding on cadherin structure and function using terbium, which is a commonly used lanthanide for protein spectroscopy and a proposed anti-cancer agent. We demonstrate that terbium can compete with calcium for binding to calcium-binding sites in cadherins. Terbium binding to cadherins abolished their cell adhesive activity and rendered cadherins sensitive to proteolysis by trypsin. Molecular dynamics simulations indicate that replacement of calcium by terbium results in structural rearrangements and increases the flexibility of the cadherin ectodomain. These changes in structure and dynamics are likely to underlie the inability of lanthanide-bound cadherins to support cell adhesion. Taken together, our findings further knowledge on lanthanide interactions with calcium-binding proteins and provide new insight into the influence of metal chemistry on cadherin structure, dynamics and function.
\end{abstract}

Significance to metallomics

Lanthanides are widely used in medicine and biological research. A unique feature of lanthanides is their ability to mimic calcium in biological processes and the binding of lanthanides is known to induce a range of effects in calcium-binding proteins. This study investigated the effect of lanthanides binding to cadherins, which are calcium-dependent cell adhesion molecules that have key roles in embryo development and tumour metastasis. Our findings expand knowledge on the bioactivity of lanthanides and provide new insight into the sensitivity of cadherin function to the chemistry of binding metals.

\section{Introduction}

Lanthanides are a group of metals with extensive use in biological research and medicine. ${ }^{1-4}$ They are frequently used in clinical magnetic resonance imaging and, due to their spectroscopic properties, are powerful tools for probing physiological processes. For example, lanthanides have been used to monitor $\mathrm{E}$ - and $\mathrm{N}$-cadherin dynamics in the membranes of cells undergoing

\footnotetext{
${ }^{a}$ Research Department of Cell and Developmental Biology, UCL, Gower Street, WC1E 6BT, London, UK. E-mail: Stephen.price@ucl.ac.uk

${ }^{b}$ Centre for Human Development, Stem Cells, and Regeneration,

University of Southampton, Southampton, SO17 1BJ, UK

${ }^{c}$ Research Department of Respiratory Medicine, UCL, Gower Street, WC1E 6BT, London, UK

$\dagger$ Electronic supplementary information (ESI) available. See DOI: 10.1039/c8mt00317c
}

epithelial-to-mesenchymal transition. ${ }^{5}$ Additionally, lanthanides are highly bioactive and there is significant interest in their use as therapeutics. ${ }^{6}$ Lanthanum carbonate for instance, is a potent binder of phosphate and is an approved treatment for hyperphosphatemia in patients with chronic kidney disease. ${ }^{7}$ Furthermore, considerable research exists to support the use of lanthanides (in particular $\mathrm{Tb}^{3+}$ and $\mathrm{Gd}^{3+}$ ) as anti-cancer agent, given their ability to induce apoptosis and inhibit cell motility in cancer cells. $^{8-11}$

A significant characteristic of lanthanide ions is their chemical similarity to $\mathrm{Ca}^{2+}$ ions, which is a result of their comparable ionic radii and metal coordination chemistry. ${ }^{12}$ For example, $\mathrm{Tb}^{3+}$ has an ionic radius of $0.98 \AA$ and $\mathrm{Ca}^{2+}$ has an ionic radius of $1.06 \AA$, and both are typically coordinated by $6-8$ ligands. ${ }^{13-15}$ Lanthanides binding within a number of $\mathrm{Ca}^{2+}$-binding 
proteins has been demonstrated, and due to their greater electropositivity, lanthanides often have a stronger binding affinity to proteins than $\mathrm{Ca}^{2+} \cdot{ }^{16,17}$ However, the effect that lanthanide binding has on the function of proteins is hard to predict. For certain proteins, lanthanide binding has been shown to effectively substitute for $\mathrm{Ca}^{2+}$ in terms of protein function. ${ }^{18,19}$ For example, $\mathrm{Tb}^{3+}$ binding to $\beta 1$-bungarotoxin stimulates the protein's phospholipase A2 activity. ${ }^{20}$ For others, such as $\mathrm{Gd}^{3+}$ binding to stretch activated $\mathrm{Ca}^{2+}$ channels, lanthanide ions have a potent inhibitory effect. ${ }^{21-23}$ Given their wide-ranging application in biology, it is important to understand the bioactivity of lanthanides on $\mathrm{Ca}^{2+}$-binding proteins.

Cadherins are a large family of calcium-dependent membrane proteins with over 100 members. Cadherins have vital roles in embryo development and tissue homeostasis, and a number of human diseases, such as cancer, are associated with alterations in cadherin function. ${ }^{24-27}$ Cadherins facilitate cell-cell adhesion through trans-binding of their extracellular regions, which are known as ectodomains. ${ }^{28}$ The ectodomains of classical cadherins are composed of five extracellular domains (EC1-5), which are connected by flexible linker regions. X-ray crystal structures indicate that three $\mathrm{Ca}^{2+}$ ions can bind at each of the four linker regions and that the cadherin protein gradually attains its functional conformation as $\mathrm{Ca}^{2+}$ ions bind to the 12 binding sites. ${ }^{29-31}$ Successive $\mathrm{Ca}^{2+}$-binding results in the precise relative positioning of EC domains and imparts rigidity and curvature onto the cadherin molecule which is an essential feature for cadherin function. ${ }^{32-34}$ Furthermore, as $\mathrm{Ca}^{2+}$ ions bind to a cadherin molecule, the binding affinity for successive $\mathrm{Ca}^{2+}$ ions increases due to cooperativity in binding and conformational changes which are transmitted distally along the cadherin. ${ }^{35,36}$ Whether lanthanides can bind cadherins and effectively replace calcium in supporting cadherin function has not been comprehensively investigated.

In this study, we investigated the binding of the lanthanide $\mathrm{Tb}^{3+}$ to two classical cadherins with fundamental functions in embryo development and tumour metastasis, E-cadherin and N-cadherin. Cell-based assays, protein biophysics and molecular dynamics have been used to demonstrate that $\mathrm{Tb}^{3+}$ competes with $\mathrm{Ca}^{2+}$ for binding to cadherin $\mathrm{Ca}^{2+}$-binding sites, and $\mathrm{Tb}^{3+}$-bound cadherins have enhanced flexibility and do not support cell-cell adhesion.

\section{Methods}

\section{Cell culture}

Chinese hamster ovary cells were stably transfected with human N-cadherin ( $\mathrm{N}-\mathrm{CHO}$ cells) or human E-cadherin (E-CHO cells) using Lipofectamine 2000 (Thermo), and cells were selected for expression using G418 (Gibco). Parental CHO, N-CHO and E-CHO cells were cultured in DMEM/F12 1:1 (Gibco) containing 10\% FBS (Gibco). Hs578t and MCF-7 cells were obtained from ATCC and were cultured in DMEM containing $10 \%$ FBS. Culture media for Hs578t additionally contained $10 \mu \mathrm{g} \mathrm{mL}^{-1}$ bovine insulin (Sigma).

\section{Aggregation assays}

Monolayer cell cultures were treated with $0.01 \%$ trypsin $+1 \mathrm{mM}$ $\mathrm{CaCl}_{2}$ in HBSS (Gibco) for 30 minutes at $37{ }^{\circ} \mathrm{C}$. This trypsin treatment dissociates monolayers into single cells whilst leaving surface cadherins intact. Cells were resuspended in HBSS $+1 \%$ BSA (Sigma) $+10 \%$ FBS to inhibit further trypsin degradation and then resuspended in HBSS $+1 \%$ BSA to give a concentration of 150000 cells per $50 \mu \mathrm{L}$. 150000 cells were seeded into 24-well ultra-low attachment plates (Corning Costar) in $0.5 \mathrm{~mL} \mathrm{HBSS}+1 \%$ BSA containing $\mathrm{CaCl}_{2}, \mathrm{TbCl}_{3}$ or combinations of both. Plates were rotated horizontally at $75 \mathrm{rpm}$ at $37{ }^{\circ} \mathrm{C}$ on an orbital shaker Model 3500 (WR) for either 30 minutes (N-CHO) or 40 minutes (E-CHO, Hs578t, MCF-7). The aggregation potential was calculated by 1 minus the number of single cells at end of aggregation $\left(N_{\mathrm{e}}\right)$ divided by the number of single cells at the beginning of aggregation $\left(N_{\mathrm{s}}\right)$. Aggregation potential $=1-N_{\mathrm{e}} / N_{\mathrm{s}}$. The number of single cells was quantified using a $0.2 \mathrm{~mm}$ Improved Neubauer haemocytometer counting chamber (Hawksley).

\section{Trypsin protection assays}

$1.5 \times 10^{6}$ cells were seeded into $10 \mathrm{~cm}$ culture plates (Triple Red) with media $24 \mathrm{~h}$ prior to experimentation. The cells were washed twice with HBSS and then incubated with HBSS + $5 \mathrm{mM}$ EDTA for $8 \mathrm{~min}$ to remove $\mathrm{Ca}^{2+}$ ions. Cells were washed with HBSS and then incubated with HBSS + required ions $\left(\mathrm{Ca}^{2+}, \mathrm{EGTA}, \mathrm{Tb}^{3+}\right)$ for $10 \mathrm{~min}$. Trypsin (Sigma) was added to a final concentration of $0.04 \%$ and cells were incubated for $80 \mathrm{~min}$ at $25{ }^{\circ} \mathrm{C}$. Cells were then pelleted, resuspended in HBSS $+0.5 \mathrm{mg}$ trypsin inhibitor (Sigma) and placed on ice.

\section{Western blotting}

Cells were lysed and protein collected using MEM-PER Plus membrane extraction kit (Thermo) with trypsin inhibitor and Halt protease inhibitor cocktail (Thermo). Protein concentration in samples was quantified using Pierce BCA Protein Assay Kit (Thermo). Samples were boiled in SDS-DTT sample buffer for $5 \mathrm{~min}$, separated on an 8\% SDS-polyacrylamide gel and then transferred to a nitrocellulose membrane (Biorad). The membrane was blocked with TBS-T (tris buffered saline plus $0.1 \%$ Tween) $+5 \%$ milk for 1 hour at room temperature and then incubated with primary antibody diluted in TBS-T + $5 \%$ milk overnight at $4{ }^{\circ} \mathrm{C}$. Membranes were washed four times in TBS-T and incubated with secondary antibody for 1 hour at $25{ }^{\circ} \mathrm{C}$. Following four further washes in TBS-T, membranes were developed with Luminata Western HRP substrate (Millipore) and exposed using a ChemiDoc MP system (Biorad). Image collection and analysis was performed with ImageLab software (Biorad).

Primary antibodies used include mouse anti-N-cadherin (BD Biosciences, 610920) (1:2500), mouse anti-E-cadherin (BD Biosciences, 610181) (1:2500), and rabbit anti- $\beta$-actin (Cell Signaling Technology, 4970) $(1: 1000)$. Secondary antibodies used include anti-mouse HRP-conjugate (Promega, W4021) $(1: 2000)$ and anti-rabbit HRP-conjugate (Promega, W4011) $(1: 2000)$. 


\section{Tb $^{3+}$-FRET}

Wild-type human E-cadherin recombinant protein fragment aa155-710 (Sigma) was dialysed within $2 \times 5$ L $10 \mathrm{mM}$ Tris$\mathrm{HCl}, 100 \mathrm{mM} \mathrm{KCl}, 120 \mathrm{mM} \mathrm{NaCl}$ (all Sigma) pH 7.4 at $4{ }^{\circ} \mathrm{C}$ using Slide-A-Lyzer Dialysis cassettes (Thermo). The protein sample was aliquoted and stored at $-20{ }^{\circ} \mathrm{C}$. E-cadherin titration and $\mathrm{Tb}^{3+}$ titration experiments were carried out on a SpectraMax-M5 (Molecular Devices). For the E-cadherin titration, a stock solution of E-cadherin was added to $100 \mu \mathrm{M} \mathrm{TbCl}{ }_{3}$ in buffer (10 mM Tris- $\mathrm{HCl}, 100 \mathrm{mM} \mathrm{KCl,} 120 \mathrm{mM} \mathrm{NaCl}$ ) or buffer alone and emission at $543 \mathrm{~nm}$ measured during excitation at $282 \mathrm{~nm}$. For the $\mathrm{Tb}^{3+}$ titration, a stock solution of $\mathrm{Tb}^{3+}$ was added to $43.7 \mathrm{nM}$ E-cadherin in buffer and emission at $543 \mathrm{~nm}$ measured during excitation at $282 \mathrm{~nm}$. The fluorescence competition assay was carried out on a Cary Eclipse Fluorescence Spectrophotometer (Agilent). Stock concentrations of $\mathrm{Ca}^{2+}$ were added to $3 \mu \mathrm{M}$ E-cadherin in $170 \mu \mathrm{M} \mathrm{Tb}{ }^{3+}$ and buffer. Emission was measured at $542 \mathrm{~nm}$ during excitation at $280 \mathrm{~nm}$. For all experiments, spectra were corrected for the background contribution of $\mathrm{Tb}^{3+}$ to $542-$ $543 \mathrm{~nm}$ emissions by measuring and subtracting the $542-543 \mathrm{~nm}$ emissions of each $\mathrm{Tb}^{3+}$ concentration in the absence of protein. All samples were gently mixed and allowed to equilibrate for 15 minutes prior to data collection.

\section{Molecular dynamics}

The LEaP software, part of AmberTools, was used to generate systems from the crystal structure of mouse E-cadherin (PDB code 3Q2V). ${ }^{31,37}$ Residues 504-507 were not resolved by crystallography and were modelled in using Pymol. ${ }^{38}$ Disulphide bridges found in physiological conditions were generated in all systems. ${ }^{31}$ The Ca-Ecad system consisted of the protein and the 12 crystallographically resolved $\mathrm{Ca}^{2+}$ ions found at the linker regions between EC domains. All 12 crystallographically resolved $\mathrm{Ca}^{2+}$ ions were replaced with $\mathrm{Tb}^{3+}$ ions for the Tb-Ecad system, and the $12 \mathrm{Ca}^{2+}$ ions were removed for the Apo-Ecad system. All other crystallographically resolved nonprotein molecules were removed in systems. Systems were neutralised through the addition of bulk $\mathrm{Na}^{+}$ions and solvated explicitly in boxes of TIP3P water molecules with edges no closer than $10 \AA$ from atoms in the protein. ${ }^{39}$

Simulations were carried out using the SANDER package in Amber16 with the Parm99 parameter sets for $\mathrm{Ca}^{2+}$ and $\mathrm{Tb}^{3+}$ ions. $^{37}$ For all simulations, 2 fs time steps were used and a potential cut-off of $8 \AA$ was assumed for van der Waals interactions. Constant volume periodic boundary conditions were assumed. The systems were minimized with 500 steps of steepest descent minimization followed by 500 steps of conjugate gradient minimization using $2 \mathrm{kcal} \mathrm{mol}^{-1} \AA^{-2}$ quadratic constraints. After minimisation, the temperature of the systems was increased to $300 \mathrm{~K}$ over 2500 steps using Langevin dynamics. Free molecular dynamics simulations were then carried out for $40 \mathrm{~ns}$.

The coordinates of atoms in the systems were saved every 10 ps during simulation and trajectories were analysed in VMD. ${ }^{40,41}$ RMSDs were calculated using non-hydrogen atoms in VMD.

\section{Results}

\section{$\mathrm{Tb}^{3+}$ inhibits E-cadherin- and N-cadherin-mediated cell adhesion}

To investigate whether $\mathrm{Tb}^{3+}$ affects cadherin-mediated cell adhesion, cell aggregation assays were used which assess the ability of single cells to form cadherin-dependent aggregates. Cadherin-expressing cells were dissociated into single cells using $0.01 \%$ trypsin $+1 \mathrm{mM} \mathrm{Ca}^{2+}$ treatment, which cleaves proteins on the cell surface but does not affect cadherins. This treatment produces a single-cell population which can only form adhesions and aggregates via cadherin-mediated cell adhesion. $^{30,42,43}$ To demonstrate that this method only permits cadherin-mediated cell aggregation, parental CHO cells were treated with $0.01 \%$ trypsin $+1 \mathrm{mM} \mathrm{Ca}^{2+}$ and assayed for $40 \mathrm{~min}$ in the presence of $1 \mathrm{mM} \mathrm{Ca}^{2+}$. Parental $\mathrm{CHO}$ cells have no endogenous cadherin expression and thus no aggregation was observed (Fig. S1, ESI $\dagger$ ).

In contrast, $\mathrm{CHO}$ cells stably expressing E-cadherin (E-CHO) and $\mathrm{CHO}$ cells stably expressing N-cadherin (N-CHO) formed dense aggregates within 40 minutes and 30 minutes respectively in the presence of $1 \mathrm{mM} \mathrm{Ca}^{2+}$ (Fig. 1A and E). However, no aggregation was visible in the presence of only $1 \mathrm{mM} \mathrm{Tb}^{3+}$ (Fig. 1B and F). Quantification of aggregation through the counting of unaggregated single cells confirmed that cadherin-mediated aggregation of E-CHO and N-CHO cells is significantly reduced in $1 \mathrm{mM} \mathrm{Tb}{ }^{3+}$ compared with aggregation in $1 \mathrm{mM} \mathrm{Ca}^{2+}$ (Fig. 1I and J). Interestingly, cell aggregation in $1 \mathrm{mM}$ $\mathrm{Ca}^{2+}+1 \mathrm{mM} \mathrm{Tb}^{3+}$ was not significantly different from that in $1 \mathrm{mM}$ $\mathrm{Ca}^{2+}$, but cell aggregation was significantly inhibited for both E-CHO and N-CHO cells in the presence of $1 \mathrm{mM} \mathrm{Ca}^{2+}+2 \mathrm{mM}$ $\mathrm{Tb}^{3+}$ (Fig. 1C, D, G, H, I and J). Similar results were obtained in cell aggregation assays in the presence of another lanthanide, $\mathrm{Gd}^{3+}$, suggesting that cadherin-mediated cell adhesion is inhibited by $\mathrm{Ca}^{2+}$-mimicking lanthanides (Fig. S2, ESI $\dagger$ ).

In order to determine if $\mathrm{Tb}^{3+}$ had the same effect on cells expressing cadherins endogenously, aggregation assays using two human cancer cell lines were carried out. MCF-7 is an E-cadherin expressing breast cancer cell line and, similarly to E-CHO, MCF-7 E-cadherin mediated cell aggregation was significantly reduced in the presence of $1 \mathrm{mM} \mathrm{Tb}^{3+}$ and $1 \mathrm{mM} \mathrm{Ca}^{2+}+$ $2 \mathrm{mM} \mathrm{Tb}^{3+}$ compared with aggregation in the presence of $1 \mathrm{mM}$ $\mathrm{Ca}^{2+}$ (Fig. S3A-D, I, ESI $\dagger$ ). ${ }^{44}$ In the N-cadherin expressing breast cancer cell line Hs578t, cell aggregation was also significantly impaired in $1 \mathrm{mM} \mathrm{Tb}^{3+}$ and $1 \mathrm{mM} \mathrm{Ca}^{2+}+2 \mathrm{mM} \mathrm{Tb}^{3+}$ (Fig. S3E$\mathrm{H}, \mathrm{J}, \mathrm{ESI} \dagger)$. Taken together, the lack of aggregation in $1 \mathrm{mM} \mathrm{Tb}^{3+}$ for all cell lines indicates $\mathrm{Tb}^{3+}$ cannot substitute for $\mathrm{Ca}^{2+}$ in mediating E- and N-cadherin adhesion. Additionally, $\mathrm{Tb}^{3+}$ is able to inhibit $\mathrm{Ca}^{2+}$-dependent cadherin cell adhesion when at a higher concentration than $\mathrm{Ca}^{2+}$, suggesting competitive binding between the two metal ions for cadherins.

\section{$\mathrm{Tb}^{3+}$ does not protect E-cadherin or $\mathrm{N}$-cadherin from trypsin degradation}

To determine how $\mathrm{Tb}^{3+}$ inhibits cadherin-mediated adhesion and whether $\mathrm{Tb}^{3+}$ competes with $\mathrm{Ca}^{2+}$ for binding at $\mathrm{Ca}^{2+}$ 


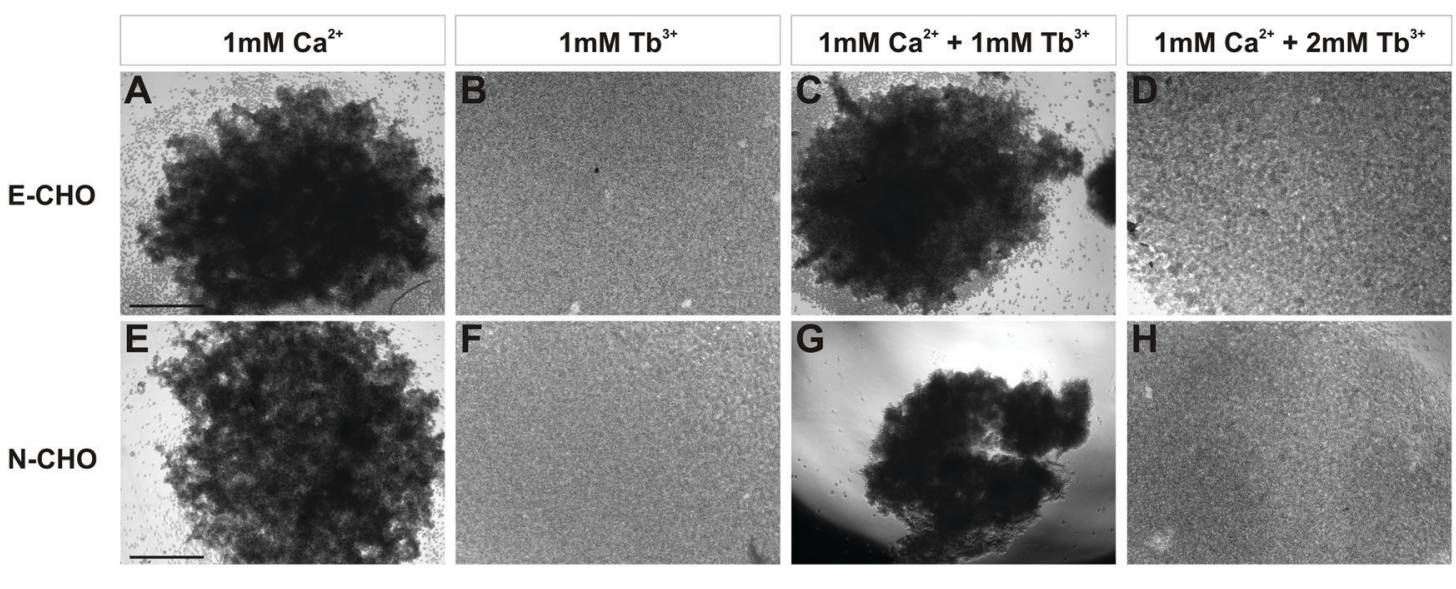

I

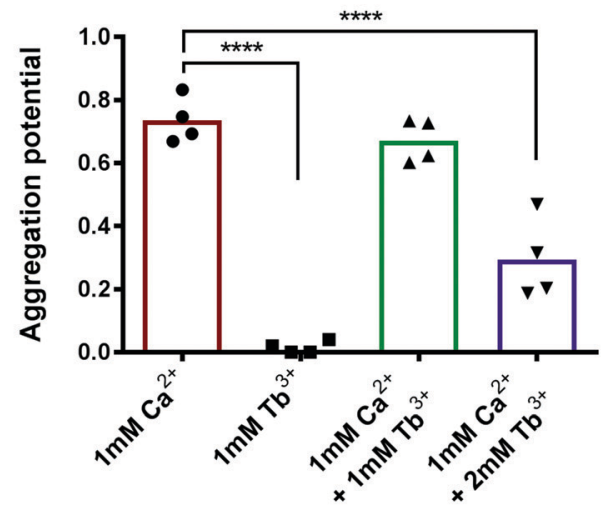

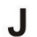

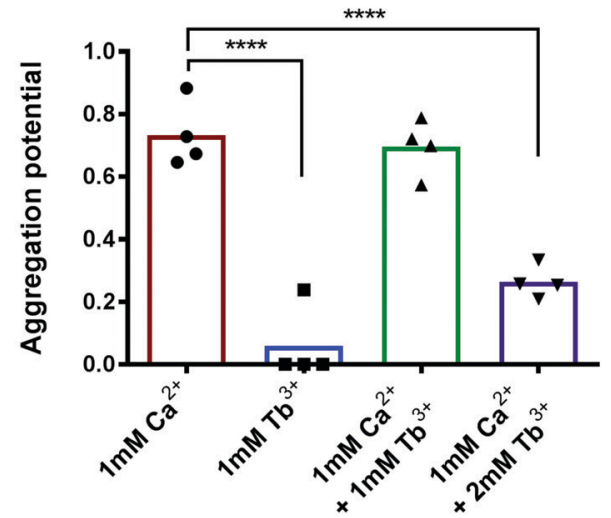

Fig. 1 Influence of $\mathrm{Tb}^{3+}$ on cadherin-mediated cell aggregation. (A-D) Cell aggregation assays of E-cadherin expressing $\mathrm{CHO}(\mathrm{E}-\mathrm{CHO})$ and $(\mathrm{E}-\mathrm{H})$ $\mathrm{N}$-cadherin expressing $\mathrm{CHO}(\mathrm{N}-\mathrm{CHO})$ cells in different combinations of $\mathrm{Ca}^{2+}$ and $\mathrm{Tb}^{3+}$. Prior to aggregation, cells were treated with $0.01 \%$ trypsin $+1 \mathrm{mM}$ $\mathrm{Ca}^{2+}$. Aggregation potential of (I) E-CHO and (J) N-CHO cells. The aggregation potential was calculated by 1 minus the number of single cells at end of aggregation $\left(N_{\mathrm{e}}\right)$ divided by the number of single cells at the beginning of aggregation $\left(N_{\mathrm{s}}\right)$. Aggregation potential $=1-N_{\mathrm{e}} / N_{\mathrm{s}}$. Scatterplots show individual values and bars represent the mean from four biological replicates (one-way ANOVA with Tukey's multiple comparisons test, significant differences are to $1 \mathrm{mM} \mathrm{CaCl}_{2}$, ****indicates $\left.p \leq 0.0001\right)$. Scale bar $=200 \mu \mathrm{m}$.

binding sites, trypsin resistance assays were carried out. When cadherins are fully bound to $\mathrm{Ca}^{2+}$, they are resistant to trypsinmediated proteolysis when using a low concentration of trypsin..$^{30,42,43}$ This is because $\mathrm{Ca}^{2+}$-bound cadherins adopt a rigid structural conformational that has no accessible trypsin recognition sites. In the absence of $\mathrm{Ca}^{2+}$ binding, cadherins adopt a flexible conformation that is sensitive to degradation as the trypsin recognition sites can become exposed. Thus, by assessing the resistance of cadherins to trypsin, we can demonstrate whether $\mathrm{Tb}^{3+}$-bound cadherins differ in structure or rigidity to $\mathrm{Ca}^{2+}$-bound cadherins and determine if $\mathrm{Tb}^{3+}$ can compete with $\mathrm{Ca}^{2+}$ for binding. Monolayers of E-CHO and $\mathrm{N}$-CHO cells were first stripped of $\mathrm{Ca}^{2+}$ via EDTA treatment and then treated with a low concentration of trypsin $(0.04 \%)$ in the presence of different combinations of $\mathrm{Ca}^{2+}$ and $\mathrm{Tb}^{3+}$ for $80 \mathrm{~min}$. Proteins were then extracted and western blots were carried out to analyse E-cadherin and $\mathrm{N}$-cadherin proteins. To measure how $\mathrm{Ca}^{2+}$ and $\mathrm{Tb}^{3+}$ protects E-cadherin and $\mathrm{N}$-cadherin from trypsin degradation, the densitometry of the protein bands corresponding to full-length cadherin proteins (120 kD for E-cadherin and $135 \mathrm{kD}$ for N-cadherin) at each condition was quantified after normalisation to a $\beta$-actin protein loading control. The densitometry of the full-length band in each treatment was expressed as relative to measurement of the full-length band in the no trypsin control.

As expected, when E-CHO cells were treated with trypsin + $1 \mathrm{mM} \mathrm{Ca}^{2+}$, there was significantly more detectable full-length E-cadherin than when E-CHO cells were treated with trypsin + 1 mM EGTA $\left(\mathrm{Ca}^{2+}\right.$ chelator), demonstrating that $\mathrm{Ca}^{2+}$ is able to protect E-cadherin from trypsin degradation (Fig. 2). However, when cells were treated with trypsin $+1 \mathrm{mM} \mathrm{Tb}^{3+}$, significant loss of full-length E-cadherin protein occurred, indicating $\mathrm{Tb}^{3+}$ offers no trypsin protection to E-cadherin. Interestingly, trypsin treatment of E-CHO cells in $1 \mathrm{mM} \mathrm{Ca}^{2+}+1 \mathrm{mM} \mathrm{Tb}^{3+}$ resulted in no significant difference in E-cadherin degradation compared with trypsin $+1 \mathrm{mM} \mathrm{Ca}^{2+}$. However, when the concentration of $\mathrm{Tb}^{3+}$ was greater than that of $\mathrm{Ca}^{2+}$, significant trypsin degradation of E-cadherin protein was observed. Trypsin resistance assays revealed similar results for N-CHO cells. Following treatment of $\mathrm{N}$-CHO cells with trypsin, $\mathrm{N}$-cadherin was significantly degraded when in the presence of $1 \mathrm{mM} \mathrm{Tb}^{3+}$ or $1 \mathrm{mM}$ $\mathrm{Ca}^{2+}+2 \mathrm{mM} \mathrm{Tb}^{3+}$ compared with N-cadherin in the presence of $1 \mathrm{mM} \mathrm{Ca}^{2+}$. Importantly, when E-CHO and N-CHO cells were incubated with the same combinations of $\mathrm{Ca}^{2+}$ and $\mathrm{Tb}^{3+}$ in the 

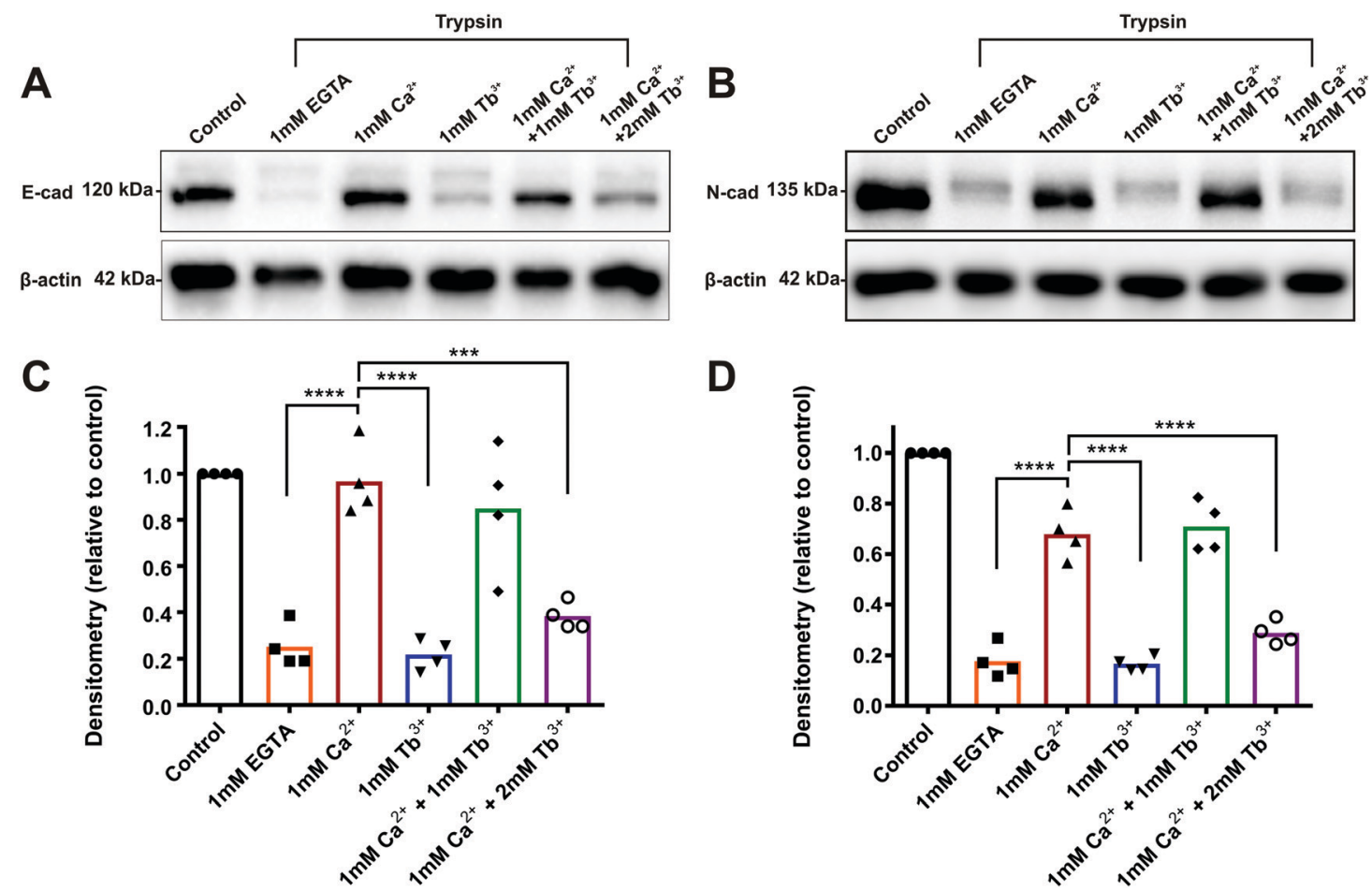

Fig. 2 Protection of E-cadherin and $\mathrm{N}$-cadherin from trypsin degradation by $\mathrm{Ca}^{2+}$ and $\mathrm{Tb}^{3+}$. Western blot of $(\mathrm{A}) \mathrm{E}$-cadherin after $\mathrm{E}-\mathrm{CHO}$ cells and of (B) $\mathrm{N}$-cadherin after $\mathrm{N}$ - $\mathrm{CHO}$ cells were treated with $0.04 \%$ trypsin in the presence of $1 \mathrm{mM} \mathrm{EGTA}, 1 \mathrm{mM} \mathrm{Ca}^{2+}, 1 \mathrm{mM} \mathrm{Tb}^{3+}, 1 \mathrm{mM} \mathrm{Ca}^{2+}+1 \mathrm{mM} \mathrm{Tb}^{3+}$, and $1 \mathrm{mM} \mathrm{Ca}^{2+}+2 \mathrm{mM} \mathrm{Tb}^{3+}$ for 80 minutes. Control cells were not treated with trypsin and $\beta$-actin was used as a loading control. (C) Quantification of E-cad expression normalised to $\beta$-actin expression and (D) $\mathrm{N}$-cadherin expression normalised to $\beta$-actin expression. Densitometry is expressed as fold change relative to the no trypsin control. Scatterplots show individual values and bars represent the mean from four biological replicates (one-way ANOVA with Tukey's multiple comparisons test, significant differences are to $1 \mathrm{mM} \mathrm{CaCl}_{2}$, $* \star \star *$ indicates $p \leq 0.0001$, ***indicates $p \leq 0.001$ ).

absence of trypsin, no significant differences in the amount of full-length cadherin were observed among the samples (Fig. S4, ESI $\dagger$ ). This demonstrates that the different ion conditions have no effect on cadherin expression levels and only effect how sensitive cadherins are to trypsin degradation.

These results show that cadherins are degraded by trypsin when in the presence of $\mathrm{Tb}^{3+}$. Given that $\mathrm{Ca}^{2+}$-bound cadherin are resistant to trypsin, this indicates that $\mathrm{Tb}^{3+}$-bound cadherins adopt a different and/or more flexible structure that has exposed trypsin recognition sites. Additionally, when $\mathrm{Tb}^{3+}$ is present at a higher concentration than $\mathrm{Ca}^{2+}$, cadherins become sensitive to trypsin degradation. This suggests that $\mathrm{Tb}^{3+}$ has the ability to displace $\mathrm{Ca}^{2+}$ from cadherins and compete with $\mathrm{Ca}^{2+}$ for binding at cadherin $\mathrm{Ca}^{2+}$-binding sites.

\section{Binding of $\mathbf{T b}^{3+}$ to E-cadherin}

The previous experiments suggest that $\mathrm{Tb}^{3+}$ binds cadherins and competes with $\mathrm{Ca}^{2+}$ for binding at $\mathrm{Ca}^{2+}$-binding sites, however direct biophysical evidence of this is required. In order to gather this evidence, we measured the fluorescence resonance energy transfer (FRET) between $\mathrm{Tb}^{3+}$ ions and human E-cadherin EC1-5 recombinant protein. $\mathrm{Tb}^{3+}$ ions are naturally fluorescent and their excitation is within the range of tryptophan and tyrosine emissions ( $348 \mathrm{~nm}$ and $303 \mathrm{~nm}$ respectively). Thus, when tryptophan and tyrosine residues in E-cadherin are excited (280-282 nm), one can quantify the amount of bound
$\mathrm{Tb}^{3+}$ ions by the FRET to $\mathrm{Tb}^{3+}$ ions and the resulting $\mathrm{Tb}^{3+}$ emission (542-543 nm).

There are $12 \mathrm{Ca}^{2+}$-binding sites that $\mathrm{Tb}^{3+}$ ions might bind to, but FRET can only take place at sites within $10 \AA$ of a tryptophan or tyrosine residue. There is no structure available for human E-cadherin EC1-5, thus the crystal structure for mouse E-cadherin EC1-5 (PDB 3Q2V) was used to identify binding sites potentially capable of FRET. The human and mouse homologues share an $81 \%$ sequence identity (450/ 553), and tryptophan (6/6) and tyrosine (13/13) residues are found in identical positions (Fig. S5B, ESI $\dagger$ ). ${ }^{31,45}$ In the mouse E-cadherin crystal structure, there are tryptophan and/or tyrosine residues within $10 \AA$ to binding sites 3 (EC1-2), 5 (EC2-3), 6 (EC2-3), 8 (EC3-4), and 10 (EC4-5) (Fig S5A, ESI $\dagger$ ). If $\mathrm{Tb}^{3+}$ ions were to bind to these sites in E-cadherin, one would expect FRET to take place.

We first determined if FRET could be measured between tryptophan and tyrosine residues in E-cadherin and $\mathrm{Tb}^{3+}$ ions in order to confirm if $\mathrm{Tb}^{3+}$ binds to E-cadherin. E-cadherin was either titrated into buffer $(10 \mathrm{mM}$ Tris- $\mathrm{HCl}, 100 \mathrm{mM} \mathrm{KCl}$, $120 \mathrm{mM} \mathrm{NaCl}$ ) or into buffer $+100 \mu \mathrm{M} \mathrm{Tb}^{3+}$, and $\mathrm{Tb}^{3+}$ fluorescence at $543 \mathrm{~nm}$ was measured following excitation at $282 \mathrm{~nm}$. In the absence of $100 \mu \mathrm{M} \mathrm{Tb} b^{3+}$, the addition of E-cadherin protein resulted in no change in $543 \mathrm{~nm}$ emission (Fig. 3A). However, addition of E-cadherin protein to $100 \mu \mathrm{M} \mathrm{Tb}^{3+}$ resulted in a linear increase of $\mathrm{Tb}^{3+}$ fluorescence emission at $543 \mathrm{~nm}$. 
This result indicates that FRET can occur between tryptophan and tyrosine residues in E-cadherin and bound $\mathrm{Tb}^{3+}$ ions, and thus suggests that $\mathrm{Tb}^{3+}$ can directly bind E-cadherin molecules.

In order to quantify the binding affinity of $\mathrm{Tb}^{3+}$ to E-cadherin, $\mathrm{Tb}^{3+}$ was titrated into a solution of E-cadherin and $543 \mathrm{~nm}$ emission was measured during $282 \mathrm{~nm}$ excitation. Data was fit to a Hill model using non-linear regression and the $K_{\mathrm{D}}$ measured by this method was $143 \mu \mathrm{M}$ (Fig. 3B). A Hill coefficient of 0.69 was obtained for the data, indicating that binding of $\mathrm{Tb}^{3+}$ to the E-cadherin protein had negative cooperativity.

A fluorescence competition assay was then carried out to determine if $\mathrm{Tb}^{3+}$ and $\mathrm{Ca}^{2+}$ compete for the same sites on E-cadherin. $\mathrm{Ca}^{2+}$ was titrated into a solution of E-cadherin in $170 \mu \mathrm{M} \mathrm{Tb}^{3+}$ and the change in $\mathrm{Tb}^{3+}$ fluorescence $(542 \mathrm{~nm})$ was measured during excitation of tryptophan and tyrosine residues $(280 \mathrm{~nm})$. Increasing the $\mathrm{Ca}^{2+}$ concentration reduced the level of $\mathrm{Tb}^{3+}$ fluorescence, suggesting displacement of $\mathrm{Tb}^{3+}$ ions at $\mathrm{Ca}^{2+}$-binding sites on E-cadherin by $\mathrm{Ca}^{2+}$ ions. Addition of $\mathrm{Ca}^{2+}$ was unable to completely remove $\mathrm{Tb}^{3+}$ fluorescence ( $\sim 60 \%$ total reduction with a half-maximal effect at $\sim 60 \mu \mathrm{M}$ ).

Differences in the molecular dynamics of $\mathrm{Ca}^{2+}$ - and $\mathrm{Tb}^{3+}$-bound E-cadherin

Our results indicate that $\mathrm{Tb}^{3+}$ can bind cadherins, but that $\mathrm{Tb}^{3+}$-bound cadherins are non-functional. In order to investigate the molecular basis of this, computational molecular dynamics simulations were performed to predict the differences in structure and dynamics of a cadherin protein bound to $\mathrm{Ca}^{2+}$ or $\mathrm{Tb}^{3+}$. Simulations were carried out using the crystal structure of the full ectodomain of E-cadherin (PDB 3Q2V) resolved to $3.4 \AA^{31}{ }^{31}$ Three scenarios based on this E-cadherin were simulated: one with the 12 crystallographically resolved $\mathrm{Ca}^{2+}$ ions (Ca-Ecad), one with the $12 \mathrm{Ca}^{2+}$ ions replaced with $\mathrm{Tb}^{3+}$ ions (Tb-Ecad) and one with the $12 \mathrm{Ca}^{2+}$ ions removed (Apo-Ecad).

The replacement of $\mathrm{Ca}^{2+}$ with $\mathrm{Tb}^{3+}$ resulted in a re-structuring of the cadherin linker regions, particularly in the charged residues in proximity to the metal ions (Fig. 4A and B). This is unsurprising given the greater electropositivity of $\mathrm{Tb}^{3+}$ ions and that $\mathrm{Tb}^{3+}$ ions typically exhibit higher coordination numbers within proteins. ${ }^{16,29,31}$ However, due to the resolution of the molecular dynamics simulations, it is not possible to comment on the exact coordination geometry and coordinating ligands of the metal ions. As expected, removal of $\mathrm{Ca}^{2+}$ in Apo-Ecad caused significant structural changes in the linker region as negative residues presumably undergo electrostatic repulsion (Fig. 4C).

Root mean-square deviations (RMSD) were used to determine how much the theoretical E-cadherin tertiary structure changed over a simulation and the RMSD was calculated for Ca-Ecad, Tb-Ecad and Apo-Ecad (Fig. 5). As observed in previous studies with other cadherin ectodomains, the E-cadherin ectodomain experienced a higher RMSD, and thus higher structural fluctuation, when in the absence of $\mathrm{Ca}^{2+}$ (Apo-Ecad, RMSD average $=9.82 \AA$ ) compared when in the presence of $\mathrm{Ca}^{2+}$ (Ca-Ecad, RMSD average $\left.=4.19 \AA\right) .{ }^{33,34,46}$ These results are also consistent with structural studies which demonstrate the

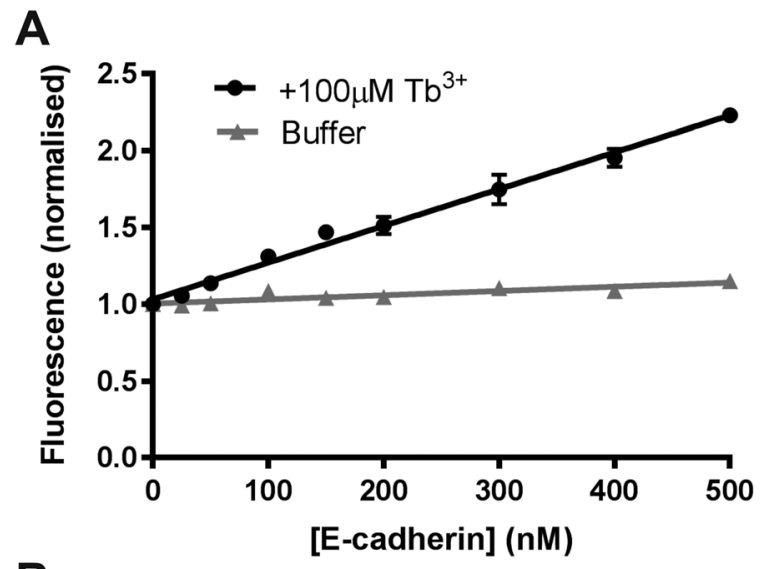

B

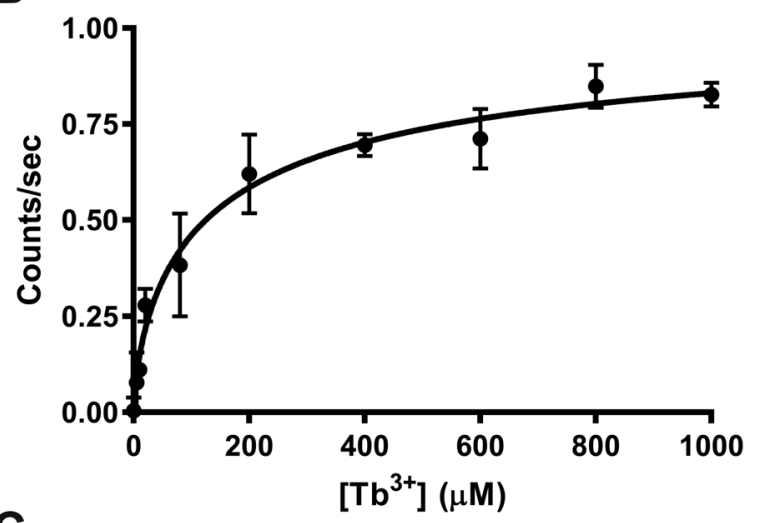

C

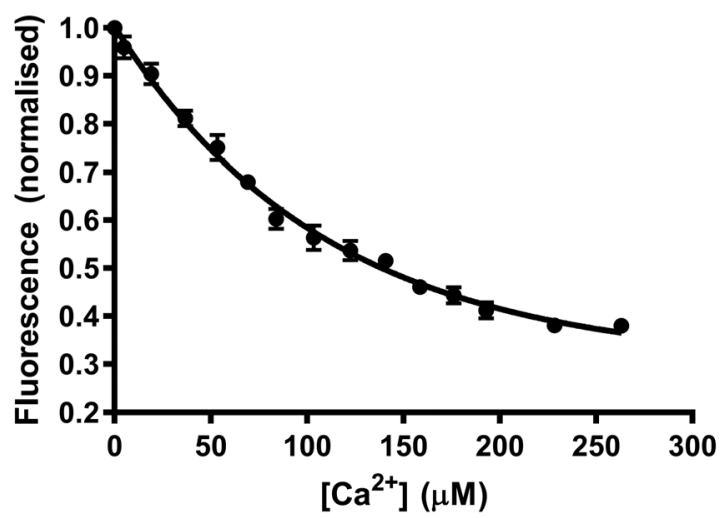

Fig. $3 \mathrm{~Tb}^{3+}$ binding to E-cadherin measured by $\mathrm{Tb}^{3+}-\mathrm{FRET}$. (A) Fluorescence at $543 \mathrm{~nm}$ in the absence and presence of $100 \mu \mathrm{M} \mathrm{Tb^{3+ }}$ when excited at $282 \mathrm{~nm}$ with increasing amounts of E-cadherin protein. Data points are normalised to fluorescence at $0 \mu \mathrm{M} \mathrm{E}$-cadherin. (B) Fluorescence at $543 \mathrm{~nm}$ during excitation at $282 \mathrm{~nm}$ when increasing concentrations of $\mathrm{Tb}^{3+}$ were added into $47.5 \mathrm{nM} \mathrm{E}$-cadherin protein. Data points are fit to a non-linear regression hill model using Graphpad Prism. (C) Fluorescence at $542 \mathrm{~nm}$ during excitation at $280 \mathrm{~nm}$ when increasing concentrations of $\mathrm{Ca}^{2+}$ were added into $3 \mu \mathrm{M} \mathrm{E}$-cadherin protein with $170 \mu \mathrm{M} \mathrm{Tb}^{3+}$. Data points are normalised to fluorescence at $0 \mu \mathrm{M} \mathrm{Ca}{ }^{2+}$. Smoothed curves are fitted for visualisation. All graphs plotted from three biological repeats; error bars represent the SEM. All measurements were performed in $10 \mathrm{mM}$ Tris- $\mathrm{HCl}$, $100 \mathrm{mM} \mathrm{KCl}, 120 \mathrm{mM} \mathrm{NaCl} \mathrm{pH} 7.4$.

rigidification of cadherin ectodomains upon $\mathrm{Ca}^{2+}$ binding. ${ }^{29,30}$ Interestingly, the E-cadherin ectodomain in the presence of $\mathrm{Tb}^{3+}$ (Tb-Ecad, RMSD average $=9.74 \AA$ ) had a high overall RMSD 
A Ca-Ecad

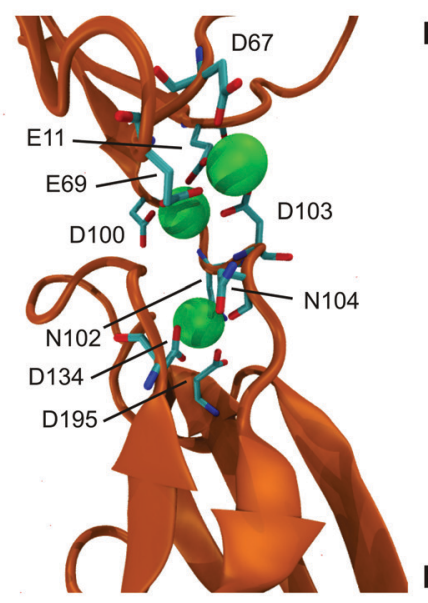

B Tb-Ecad

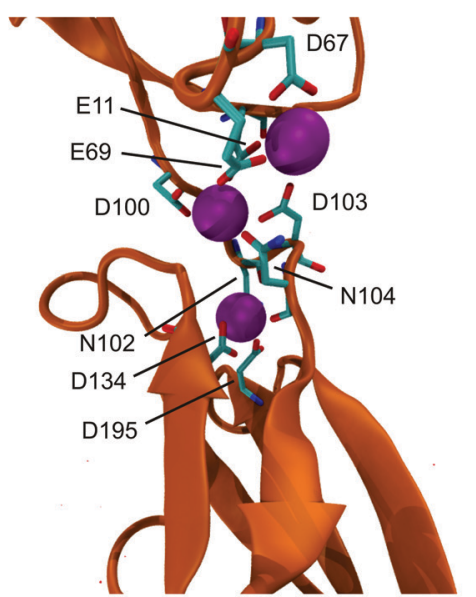

EC1

C Apo-Ecad

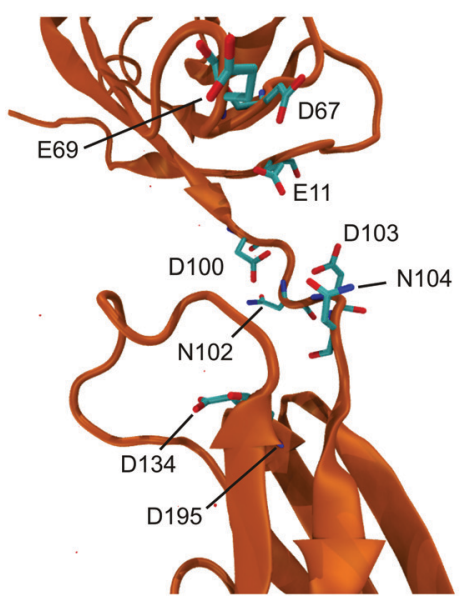

EC1

EC2

Fig. $4 \mathrm{E}$-cadherin linker regions in the presence of $\mathrm{Ca}^{2+}$ and $\mathrm{Tb}^{3+}$ ions. Snapshots of the linker region between repeats $E C 1-E C 2$ of $E$-cadherin in the presence of ( $\mathrm{A}, \mathrm{Ca}-\mathrm{Ecad}) \mathrm{Ca}^{2+},(\mathrm{B}, \mathrm{Tb}-\mathrm{Ecad}) \mathrm{Tb}^{3+}$, or (C, Apo-Ecad) absence of $\mathrm{Ca}^{2+}$ and $\mathrm{Tb}^{3+}$ ions after 40 ns of simulated free molecular dynamics. $\mathrm{Ca}^{2+}$ ions are represented as green spheres and $\mathrm{Tb}^{3+}$ ions are represented as purple spheres. Residues in proximity to metal ions are shown in liquorice representation.
A

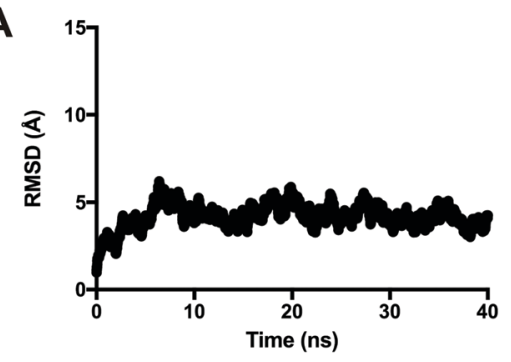

B

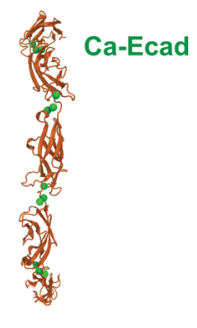

C

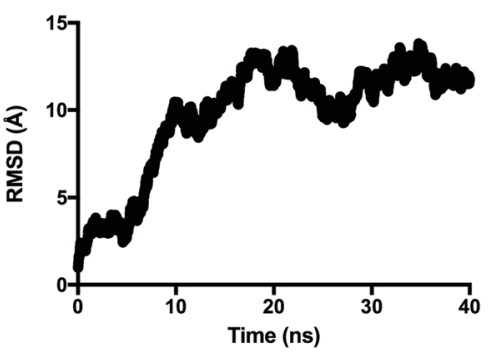

D

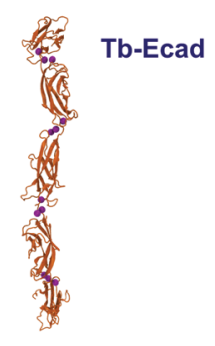

E

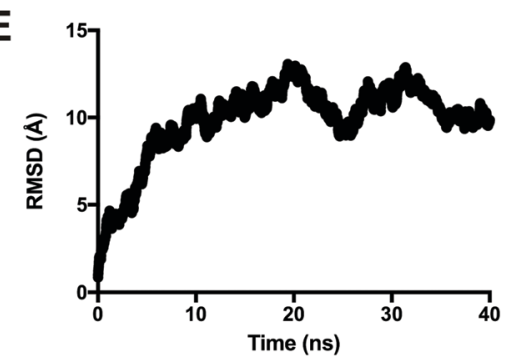

$\mathbf{F}$

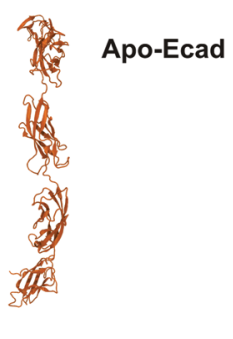

Fig. 5 Influence of $\mathrm{Ca}^{2+}$ and $\mathrm{Tb}^{3+}$ ions on the molecular dynamics of the $\mathrm{E}$-cadherin ectodomain. RMSD of the E-cadherin ectodomain in the (A, Ca-Ecad) presence of $\mathrm{Ca}^{2+},(\mathrm{C}, \mathrm{Tb}-\mathrm{Ecad})$ presence of $\mathrm{Tb}^{3+}$ or ( $\mathrm{E}, \mathrm{Apo}-\mathrm{Ecad}$ ) absence of $\mathrm{Ca}^{2+}$ and $\mathrm{Tb}^{3+}$ during $40 \mathrm{~ns}$ of simulated free molecular dynamics. (B, D and F) Snapshots of the ectodomains at the end of the simulation. $\mathrm{Ca}^{2+}$ ions are represented as green spheres and $\mathrm{Tb}^{3+}$ ions are represented as purple spheres.

that was similar to Apo-Ecad ectodomains, indicating a high level of structural flexibility. It is important to note that, like $\mathrm{Ca}^{2+}$ ions, all $\mathrm{Tb}^{3+}$ ions remained bound within the $\mathrm{Ca}^{2+}$-binding sites over the course of the simulation.

In order to compare how the structure and dynamics of the E-cadherin ectodomain differ in the presence of $\mathrm{Ca}^{2+}$ and $\mathrm{Tb}^{3+}$, the end-to-end distance and curvature of the ectodomains were measured (Fig. 6). The distance between $\alpha$-Carbon atoms of two distal residues, Glu31 and Arg451, was measured for both scenarios over the $40 \mathrm{~ns}$ simulation. It was found that the E-cadherin ectodomain had a longer average end-to-end distance when in presence of $\mathrm{Tb}^{3+}$ compared with $\mathrm{Ca}^{2+}(209.6 \AA \mathrm{A} v$. $192.6 \AA)$. The curvatures of the ectodomains were compared by measuring the angle made between $\alpha$-Carbon atoms of distal residues Glu31 and Arg451, and the residue that was closest to the geometric centre of EC3, Leu282. The curvature angle of the E-cadherin ectodomain with $\mathrm{Tb}^{3+}$ was also found to be larger than that for the ectodomain with $\mathrm{Ca}^{2+}\left(146.1^{\circ}\right.$ vs. $\left.123.4^{\circ}\right)$. Together these results suggest that the binding of $\mathrm{Tb}^{3+}$ leads to significant structural changes in the E-cadherin ectodomain and 
A

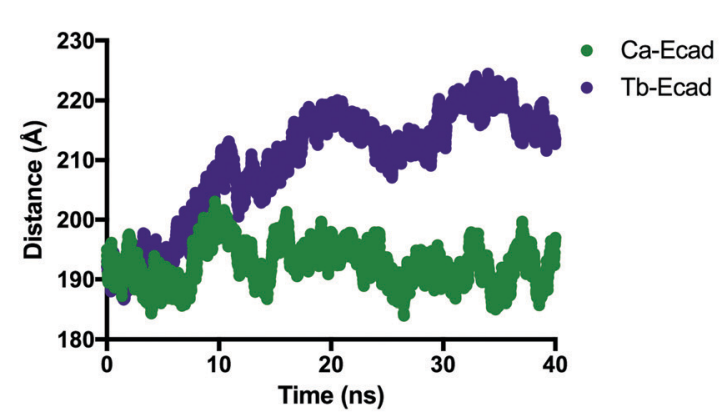

D

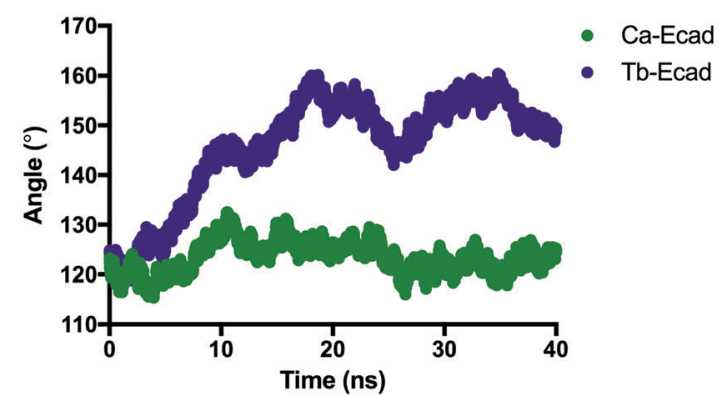

B

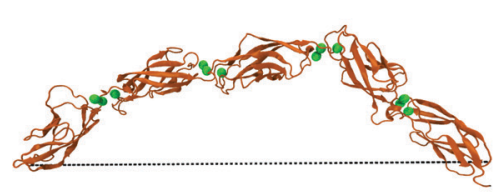

C

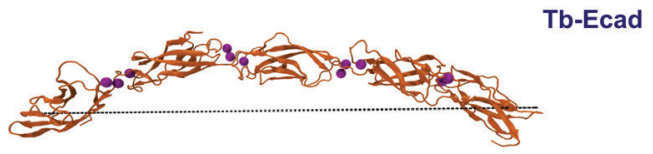

E

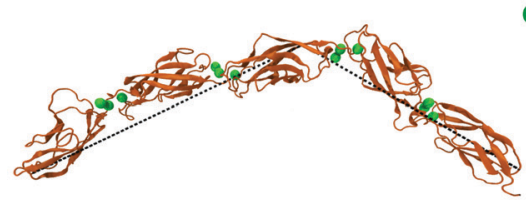

Ca-Ecad

$\mathbf{F}$

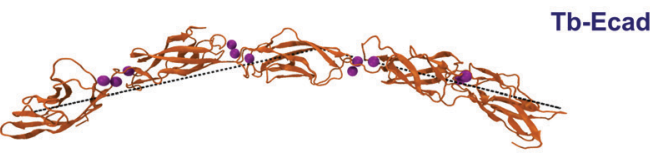

Fig. 6 Tertiary structural differences between E-cadherin bound to $\mathrm{Ca}^{2+}$ and $\mathrm{Tb}^{3+}$. (A) End-to-end distance of the E-cadherin ectodomain in the presence of $\mathrm{Ca}^{2+}(\mathrm{Ca}-\mathrm{Ecad})$ or $\mathrm{Tb}^{3+}$ (Tb-Ecad) during 40 ns of simulated free molecular dynamics. (B and C) Snapshots of the ectodomains at the end of the simulation. $\mathrm{Ca}^{2+}$ ions are represented as green spheres and $\mathrm{Tb}^{3+}$ ions are represented as purple spheres. Black dotted line indicates the end-to-end distance drawn between identical atoms in Ca-Ecad and Tb-Ecad. (D) Angle of curvature of the E-cadherin ectodomain in the presence of Ca ${ }^{2+}$ (Ca-Ecad) or $\mathrm{Tb}^{3+}$ (Tb-Ecad) during 40 ns of simulated free molecular dynamics. (E and F) Snapshots of the ectodomains at the end of the simulation. Black dotted line indicates the angle of curvature drawn between three identical atoms in Ca-Ecad and Tb-Ecad.

results in elongated structures with more shallow curvature compared with $\mathrm{Ca}^{2+}$-bound E-cadherin ectodomains. Furthermore, the Tb-Ecad ectodomain had greater fluctuation in both the end-to-end distance (Tb-Ecad, $\mathrm{SD}=9.32 \AA$ vs. Ca-Ecad, $\mathrm{SD}=$ $3.30 \AA$ ) and curvature angle (Tb-Ecad, $\mathrm{SD}=10.66^{\circ}$ vs. Ca-Ecad, $\mathrm{SD}=3.18^{\circ}$ ), which indicates greater structural flexibility in the $\mathrm{Tb}^{3+}$-bound ectodomain. The outcomes from the simulations agree well with our experimental data, which demonstrated that $\mathrm{Tb}^{3+}$-bound cadherins cannot mimic the functional conformation of $\mathrm{Ca}^{2+}$-bound cadherins.

Our molecular dynamics simulations were used here to explore the impact of metal ion chemistry on cadherin structure and dynamics and provide atomistic explanations for our experimental findings. Further experimental work, such as crystallography or NMR, would be necessary to validate these computational predictions.

\section{Discussion}

The present study shows that $\mathrm{Tb}^{3+}$ inhibits cadherin-mediated cell adhesion and our evidence suggests that this is a result of competitive binding at cadherin $\mathrm{Ca}^{2+}$-binding sites. Cadherins require $\mathrm{Ca}^{2+}$-binding at all 12 sites in order to achieve a functional conformation and loss of $\mathrm{Ca}^{2+}$-binding at a single site is sufficient to disrupt cadherin-mediated cell adhesion. ${ }^{36,47}$
Here, we demonstrate that $\mathrm{Tb}^{3+}$ functions as a competitive antagonist in $\mathrm{Ca}^{2+}$-dependent cadherin-mediated cell aggregation assays and our trypsin resistance assays suggest that $\mathrm{Tb}^{3+}$ competes with $\mathrm{Ca}^{2+}$ for binding to cadherins. Furthermore, $\mathrm{Tb}^{3+}$ is a well-documented mimic of $\mathrm{Ca}^{2+}$ in biological processes and our molecular dynamics simulations show that $\mathrm{Tb}^{3+}$ remained bound within $\mathrm{Ca}^{2+}$-binding sites throughout the simulations. This is in contrast to $\mathrm{Na}^{+}$and $\mathrm{K}^{+}$, which have no experimental evidence of binding to cadherins and these ions become unbound from cadherin $\mathrm{Ca}^{2+}$-binding sites during simulations. ${ }^{33}$ The $^{\mathrm{Tb}^{3+}}$ FRET experiments additionally provide biophysical evidence for $\mathrm{Tb}^{3+}$ binding to cadherins and suggest that $\mathrm{Tb}^{3+}$ ions compete for the same sites as $\mathrm{Ca}^{2+}$ ions.

Results from the fluorescence competition assay demonstrate that not all the observed $\mathrm{Tb}^{3+}$ fluorescence can be attributed to $\mathrm{Tb}^{3+}$ binding at $\mathrm{Ca}^{2+}$-binding sites. This might be an artefact of $\mathrm{Tb}^{3+}$ autofluorescence or potentially the result of $\mathrm{Tb}^{3+}$ binding to E-cadherin at sites other than $\mathrm{Ca}^{2+}$-binding sites. Whether $\mathrm{Tb}^{3+}$ binding at non- $\mathrm{Ca}^{2+}$-binding sites is possible and what effect this might have on cadherin structure remains to be determined.

It is not possible to determine at how many or at which $\mathrm{Ca}^{2+}$-binding sites $\mathrm{Tb}^{3+}$ ions can bind to. Only 5 out of the 12 $\mathrm{Ca}^{2+}$-binding sites in human E-cadherin are potentially reportable by FRET, and of these 5 sites one cannot accurately calculate how binding at each site would contribute to the $\mathrm{Tb}^{3+}$ fluorescence signal. For the same reasons, it is unknown 
how many $\mathrm{Tb}^{3+}$ ions could bind each E-cadherin molecule at non- $\mathrm{Ca}^{2+}$-binding sites. There might only be a very small amount of $\mathrm{Tb}^{3+}$ binding to non- $\mathrm{Ca}^{2+}$-binding sites but this binding might contribute to a large amount of the observed $\mathrm{Tb}^{3+}$ fluorescence, which is dependent on the distances between $\mathrm{Tb}^{3+}$ ions and tryptophan and tyrosine residues. Structural determination studies would be required to conclude exactly where and how $\mathrm{Tb}^{3+}$ binds to cadherins.

The ratio of $\left[\mathrm{Tb}^{3+}\right]:\left[\mathrm{Ca}^{2+}\right]$ required to inhibit cell adhesion and cadherin trypsin protection suggests that $\mathrm{Ca}^{2+}$ has a higher binding affinity than $\mathrm{Tb}^{3+}$ to cadherins. The competition fluorescence assay additionally suggests this as $\sim 60 \mu \mathrm{M} \mathrm{Ca}^{2+}$ had a half-maximal effect in reducing $\mathrm{Tb}^{3+}$ fluorescence in E-cadherin when in the presence of $170 \mu \mathrm{M} \mathrm{Tb}^{3+}$. A difference in binding affinity does not, however, fully explain why a steep dose-response relationship was observed for the cellular assays: no effect was observed at a $\left[\mathrm{Tb}^{3+}\right]:\left[\mathrm{Ca}^{2+}\right]$ ratio of $1: 1$ but effective inhibition was seen at a ratio of $2: 1$. One explanation for these results is the potential binding of $\mathrm{Tb}^{3+}$ to both $\mathrm{Ca}^{2+}$ - and non- $\mathrm{Ca}^{2+}$-binding sites on cadherins. At a ratio of $1: 1, \mathrm{~Tb}^{3+}$ might bind elsewhere on cadherins as $\mathrm{Ca}^{2+}$ occupies the $\mathrm{Ca}^{2+}$-binding sites, but at a ratio of $2: 1, \mathrm{~Tb}^{3+}$ may be at a sufficiently high concentration to outcompete $\mathrm{Ca}^{2+}$ for the $\mathrm{Ca}^{2+}$-binding sites and thus inhibit the $\mathrm{Ca}^{2+}$-dependent cadherin processes.

It would be unusual if $\mathrm{Tb}^{3+}$ had a weaker binding affinity than $\mathrm{Ca}^{2+}$ to cadherins. $\mathrm{Tb}^{3+}$ typically binds more strongly to $\mathrm{Ca}^{2+}$-binding proteins, such as calmodulin, due to the greater electropositivity of $\mathrm{Tb}^{3+} \cdot{ }^{16,17}$ One possible explanation for the apparent higher binding affinity of $\mathrm{Ca}^{2+}$ to cadherins is that $\mathrm{Ca}^{2+}$ binds to the 12 sites on cadherins with a high level of coorperativity. ${ }^{35,36,48}$ Binding of $\mathrm{Ca}^{2+}$ to one $\mathrm{Ca}^{2+}$-binding site induces specific structural changes that enhances the binding affinity of $\mathrm{Ca}^{2+}$ to the other sites on a cadherin molecule. Given that the extensive cooperativity of $\mathrm{Ca}^{2+}$ binding requires a precise network of molecular interactions across 12 binding sites, it is plausible that slight differences in metal chemistry result in $\mathrm{Tb}^{3+}$ being unable to mimic the cooperative binding of $\mathrm{Ca}^{2+}$ to cadherins. Results from the $\mathrm{Tb}^{3+}$ FRET assay suggest that $\mathrm{Tb}^{3+}$ binds to E-cadherin with negative cooperativity $\left(K_{\mathrm{D}}=143 \mu \mathrm{M}\right.$, hill coefficient $\left.=0.69\right)$, however values from this experiment should be treated with caution, as they are not specific for $\mathrm{Tb}^{3+}$ binding to only $\mathrm{Ca}^{2+}$-binding sites. Overall, it is possible that $\mathrm{Ca}^{2+}$-cooperative binding may be essential for cadherin's preferential binding of $\mathrm{Ca}^{2+}$ over other ions. This may be one mechanism by which cadherins maintain robust function in stochastic biological environments.

Upon $\mathrm{Tb}^{3+}$ binding to cadherins, data from trypsin protection assays indicate that cadherins differ in structure and/or conformational flexibility to $\mathrm{Ca}^{2+}$-bound cadherins. Molecular dynamics simulations support these findings and suggest that $\mathrm{Tb}^{3+}$-bound cadherins have a more elongated, less curved structure that exhibits enhanced structural fluctuations. These changes in tertiary structure are likely responsible for the inability of $\mathrm{Tb}^{3+}$-bound cadherins to support cell adhesion. Interestingly, a recent study found that binding of $\mathrm{Tb}^{3+}$ to another $\mathrm{Ca}^{2+}$-dependent protein, calmodulin, resulted in enhanced structural flexibility within $\mathrm{Ca}^{2+}$-binding sites and this was caused by the more electropositive $\mathrm{Tb}^{3+}$ adopting an alternative and more disordered coordination geometry. ${ }^{49}$ In the case of cadherins, changes in coordination geometry and flexibility within binding sites may also be the chemical driving forces behind global differences in $\mathrm{Tb}^{3+}$-bound and $\mathrm{Ca}^{2+}$-bound molecules. However, unlike in calmodulin, cadherins are non-functional upon binding to $\mathrm{Tb}^{3+}$, which provides further insight into the high level of sensitivity of cadherins to $\mathrm{Ca}^{2+}$ chemistry. ${ }^{50,51}$ Overall, it is fascinating that seemingly slight differences in the chemistry between $\mathrm{Tb}^{3+}$ and $\mathrm{Ca}^{2+}$ can significantly influence the structure, dynamics and function of cadherin proteins. Follow-on structural determination studies would be invaluable in providing conclusive evidence for how substitution of $\mathrm{Ca}^{2+}$ with $\mathrm{Tb}^{3+}$ affects the tertiary structure of cadherins and interactions within the binding sites.

We also show that $\mathrm{Gd}^{3+}$ inhibits cadherin adhesion in a similar $\mathrm{Ca}^{2+}$-competing manner and there is some evidence of $\mathrm{La}^{3+}$ competing with $\mathrm{Ca}^{2+}$ for binding to cadherins. ${ }^{52}$ Many lanthanide ions are known to chemically mimic $\mathrm{Ca}^{2+}$ and the $\mathrm{Ca}^{2+}$-binding pockets of classical cadherins are highly conserved, thus one would predict that the interaction elucidated here is universal between lanthanides and classical cadherins. ${ }^{16,53}$

\section{Conclusion}

Cadherin adhesions have widespread roles in physiology and there is a growing appreciation for how the interaction of cadherins with non- $\mathrm{Ca}^{2+}$ ions can regulate cadherin function. For example, $\mathrm{Zn}^{2+}$ ions have been shown to bind and inhibit $\mathrm{N}$-cadherin binding and this interaction is believed to play a regulatory role in synaptic plasticity. ${ }^{54,55}$ Here, the lanthanide $\mathrm{Tb}^{3+}$, which has applications in protein spectroscopy and cancer therapy, was found to compete with $\mathrm{Ca}^{2+}$ for binding to cadherins. We show that $\mathrm{Tb}^{3+}$-bound cadherins are unable to support cell adhesion and demonstrate this is a result of differences in the structure and dynamics of cadherins following $\mathrm{Ca}^{2+}$ - and $\mathrm{Tb}^{3+}$-binding. Unlike in other $\mathrm{Ca}^{2+}$-dependent proteins, $\mathrm{Tb}^{3+}$ cannot functionally-replace $\mathrm{Ca}^{2+}$ in cadherins and our work provides new insight into the sensitivity of cadherin structure, dynamics and function to the chemistry of $\mathrm{Ca}^{2+}$. Furthermore, our characterisation of the interaction between lanthanides and cadherins should be of value as lanthanides continue to be used in biology and medicine.

\section{Abbreviations}

$\begin{array}{ll}\mathrm{Ca}^{2+} & \text { Calcium } \\ \mathrm{Tb}^{3+} & \text { Terbium } \\ \mathrm{Gd}^{3+} & \text { Gadolinium } \\ \mathrm{EC} & \text { Extracellular domain } \\ \text { FRET } & \text { Fluorescence resonance energy transfer } \\ \text { N-CHO } & \text { N-Cadherin expressing CHO cell } \\ \text { E-CHO } & \text { E-Cadherin expressing CHO cell }\end{array}$


aa Amino acids

RMSD Root mean square deviation

SEM Standard error of the mean

\section{Financial support}

This work was funded by the BBSRC, EPSRC and Wellcome Trust of the UK.

\section{Conflicts of interest}

The authors indicate no potential conflicts of interest.

\section{Acknowledgements}

We thank Dr Anwen Brown, Dr Shaline Fazal and Dr Tina Daviter for technical assistance.

\section{References}

1 E. Blumfield, M. M. Moore, M. K. Drake, T. R. Goodman, K. N. Lewis, L. T. Meyer, T. D. Ngo, C. Sammet, A. L. Stanescu, D. W. Swenson, T. L. Slovis and R. S. Iyer, Survey of gadolinium-based contrast agent utilization among the members of the Society for Pediatric Radiology: a Quality and Safety Committee report, Pediatr. Radiol., 2017, 47, 665-673.

2 M. Bottrill, L. Kwok and N. J. Long, Lanthanides in magnetic resonance imaging, Chem. Soc. Rev., 2006, 35, 557-571.

3 P. Caravan, J. J. Ellison, T. J. McMurry and R. B. Lauffer, Gadolinium(III) Chelates as MRI Contrast Agents: Structure, Dynamics, and Applications, Chem. Rev., 1999, 99, 2293-2352.

4 Z. Zhou and Z.-R. Lu, Gadolinium-Based Contrast Agents for MR Cancer Imaging, Wiley Interdiscip. Rev.: Nanomed. Nanobiotechnol., 2013, 5, 1-18.

5 S. Linden, M. K. Singh, K. D. Wegner, M. Regairaz, F. Dautry, F. Treussart and N. Hildebrandt, Terbium-based time-gated Förster resonance energy transfer imaging for evaluating protein-protein interactions on cell membranes, Dalton Trans., 2015, 44, 4994-5003.

6 S. P. Fricker, The therapeutic application of lanthanides, Chem. Soc. Rev., 2006, 35, 524-533.

7 A. J. Hutchison, R. J. Wilson, S. Garafola and J. B. Copley, Lanthanum carbonate: safety data after 10 years, Nephrology, 2016, 21, 987-994.

8 I. Kostova, Lanthanides as anticancer agents, Curr. Med. Chem.: Anti-Cancer Agents, 2005, 5, 591-602.

9 J. L. Cox, T. Lancaster and C. G. Carlson, Changes in the motility of B16F10 melanoma cells induced by alterations in resting calcium influx, Melanoma Res., 2002, 12, 211-219.

10 Y. Dai, J. Li, J. Li, L. Yu, G. Dai, A. Hu, L. Yuan and Z. Wen, Effects of rare earth compounds on growth and apoptosis of leukemic cell lines, In Vitro Cell. Dev. Biol.: Anim., 2002, 38, $373-375$.
11 P. Shi and Z. Huang, Proteomic detection of changes in protein synthesis induced by lanthanum in BGC-823 human gastric cancer cells, Biometals, 2005, 18, 89-95.

12 W. D. Horrocks and D. R. Sudnick, Lanthanide Ion Probes of Structure in Biology. Laser- Induced Luminescence Decay Constants Provide a Direct Measure of the Number of Metal-Coordinated Water Molecules, J. Am. Chem. Soc., 1979, 101, 334-340.

13 A. K. Katz, J. P. Glusker, S. A. Beebe and C. W. Bock, Calcium ion coordination: A comparison with that of beryllium, magnesium, and zinc, J. Am. Chem. Soc., 1996, 118, 5752-5763.

14 R. D. Shannon, Revised effective ionic radii and systematic studies of interatomic distances in halides and chalcogenides, Acta Crystallogr., Sect. A: Cryst. Phys., Diffr., Theor. Gen. Crystallogr., 1976, 32, 751-767.

15 E. E. Snyder, B. W. Buoscio and J. J. Falke, Calcium(II) site specificity: effect of size and charge on metal ion binding to an EF-hand-like site, Biochemistry, 1990, 29, 3937-3943.

16 E. Pidcock and G. R. Moore, Structural characteristics of protein binding sites for calcium and lanthanide ions, J. Biol. Inorg. Chem., 2001, 6, 479-489.

17 S. M. Mustafi, S. Mukherjee, K. V. R. Chary, C. Del Bianco and C. Luchinat, Energetics and Mechanism of $\mathrm{Ca}^{2+}$ Displacement by Lanthanides in a Calcium Binding Protein, Biochemistry, 2004, 43, 9320-9331.

18 B. C. Furie, K. G. Mann and B. Furie, Substitution of lanthanide ions for calcium in the activation of bovine prothrombin by activated factor $\mathrm{X}$ : high affinity metal binding sites, J. Biol. Chem., 1976, 251, 3235-3241.

19 A. D. Sherry, A. D. Newman and C. G. Gutz, The activation of concanavalin A by lanthanide ions, Biochemistry, 1975, 14, 2191-2196.

20 S. T. Chu and Y. H. Chen, The intrinsic tryptophan fluorescence of beta 1-bungarotoxin and the $\mathrm{Ca}^{2+}$-binding domains of the toxin as probed with $\mathrm{Tb}^{3+}$ luminescence., Biochem. J., 1989, 262, 773-779.

21 L. C. Adding, G. L. Bannenberg and L. E. Gustafsson, Basic experimental studies and clinical aspects of gadolinium salts and chelates, Cardiovasc. Drug Rev., 2001, 19, 41-56.

22 C. R. Halaszovich, C. Zitt, E. Jungling and A. Luckoff, Inhibition of TRP3 channels by lanthanides. Block from the cytosolic side of the plasma membrane, J. Biol. Chem., 2000, 275, 37423-37428.

23 Y. Wu, Lanthanide ions inhibit the activity of dihydrofolate reductase from chicken liver, Biometals, 2000, 13, 195-201.

24 M. Astick, K. Tubby, W. M. Mubarak, S. Guthrie and S. R. Price, Central topography of cranial motor nuclei controlled by differential cadherin expression, Curr. Biol., 2014, 24, 2541-2547.

25 L. L. Brayshaw and S. R. Price, in The Cadherin Superfamily: Key Regulators of Animal Development and Physiology, ed. T. S. Suzuki and S. Hirano, Springer, Japan, Tokyo, 2016, pp. 315-340.

26 H. G. Munshi, S. Ghosh, S. Mukhopadhyay, Y. I. Wu, R. Sen, K. J. Green and M. S. Stack, Proteinase suppression by E- 
cadherin-mediated cell-cell attachment in premalignant oral keratinocytes, J. Biol. Chem., 2002, 277, 38159-38167.

27 A. Jeanes, C. Gottardi and A. Yap, Cadherins and cancer: how does cadherin dysfunction promote tumor progression?, Oncogene, 2008, 27, 6920-6929.

28 D. Leckband and A. Prakasam, Mechanism and dynamics of cadherin adhesion, Annu. Rev. Biomed. Eng., 2006, 8, 259-287.

29 O. Pertz, D. Bozic, A. W. Koch, C. Fauser, A. Brancaccio and J. Engel, A new crystal structure, $\mathrm{Ca}^{2+}$ dependence and mutational analysis reveal molecular details of E-cadherin homoassociation, EMBO J., 1999, 18, 1738-1747.

30 S. Pokutta, K. Herrenknecht, R. Kemler and J. Engel, Conformational changes of the recombinant extracellular domain of E-cadherin upon calcium binding, Eur. J. Biochem., 1994, 223, 1019-1026.

31 O. J. Harrison, X. Jin, S. Hong, F. Bahna, G. Ahlsen, J. Brasch, Y. Wu, J. Vendome, K. Felsovalyi, C. M. Hampton, R. B. Troyanovsky, A. Ben-Shaul, J. Frank, S. M. Troyanovsky, L. Shapiro and B. Honig, The extracellular architecture of adherens junctions revealed by crystal structures of type I cadherins, Structure, 2011, 19, 244-256.

32 T. J. Boggon, J. Murray, S. Chappuis-Flament, E. Wong, B. M. Gumbiner and L. Shapiro, Science, 2002, 296, 1308-1313.

33 M. Sotomayor and K. Schulten, The allosteric role of the $\mathrm{Ca}^{2+}$ switch in adhesion and elasticity of C-cadherin, Biophys. J., 2008, 94, 4621-4633.

34 J. Oroz, A. Valbuena, A. M. Vera, J. Mendieta, P. GomezPuertas and M. Carrion-Vazquez, Nanomechanics of the cadherin ectodomain: 'Canalization' by $\mathrm{Ca}^{2+}$ binding results in a new mechanical element, J. Biol. Chem., 2011, 286, 9405-9418.

35 O. Courjean, G. Chevreux, E. Perret, A. Morel, S. Sanglier, N. Potier, J. Engel, A. Van Dorsselaer and H. Feracci, Modulation of E-cadherin monomer folding by cooperative binding of calcium ions, Biochemistry, 2008, 47, 2339-2349.

36 A. Prakasam, Y. H. Chien, V. Maruthamuthu and D. E. Leckband, Calcium site mutations in cadherin: impact on adhesion and evidence of cooperativity, Biochemistry, 2006, 45, 6930-6939.

37 D. A. Case, R. M. Betz, W. Botello-Smith, D. S. Cerutti, T. E. Cheatham, III, T. A. Darden, R. E. Duke, T. J. Giese, H. Gohlke, A. W. Goetz, N. Homeyer, S. Izadi, P. Janowski, J. Kaus, A. Kovalenko, T. S. Lee, S. LeGrand, P. Li, C. Lin, T. Luchko, R. Luo and B. Madej, AMBER 2016, University of California, San Francisco, 2016.

38 L. Schrödinger, The PyMOL Molecular Graphics System, Version 1.8, 2015.

39 W. L. Jorgensen, J. Chandrasekhar, J. D. Madura, R. W. Impey and M. L. Klein, Comparison of simple potential functions for simulating liquid water, J. Chem. Phys., 1983, 79, 926.

40 W. Humphrey, A. Dalke and K. Schulten, VMD-Visual Molecular Dynamics, J. Mol. Graphics, 1996, 14, 33-38.
41 J. Eargle, D. Wright and Z. Luthey-Schulten, Multiple Alignment of protein structures and sequences for VMD, Bioinformatics, 2006, 22, 504-506.

42 M. Takeichi, Functional correlation between cell adhesive properties and some cell surface proteins, J. Cell Biol., 1977, 75, 464-474.

43 M. Takeichi, Cadherins: a molecular family important in selective cell-cell adhesion, Annu. Rev. Biochem., 1990, 59, 237-252.

44 L. Hughes, C. Malone, S. Chumsri, A. M. Burger and S. McDonnell, Characterisation of breast cancer cell lines and establishment of a novel isogenic subclone to study migration, invasion and tumourigenicity, Clin. Exp. Metastasis, 2008, 25, 549-557.

45 S. F. Altschul, T. L. Madden, A. A. Schäffer, J. Zhang, Z. Zhang, W. Miller and D. J. Lipman, Gapped BLAST and PSI-BLAST: a new generation of protein database search programs, Nucleic Acids Res., 1997, 25, 3389-3402.

46 F. Cailliez and R. Lavery, Cadherin mechanics and complexation: the importance of calcium binding, Biophys. J., 2005, 89, 3895-3903.

47 M. Ozawa, J. Engel and R. Kemler, Single amino acid substitutions in one $\mathrm{Ca}^{2+}$ binding site of uvomorulin abolish the adhesive function, Cell, 1990, 63, 1033-1038.

48 J. R. Alattia, J. B. Ames, T. Porumb, K. I. Tong, Y. M. Heng, P. Ottensmeyer, C. M. Kay and M. Ikura, Lateral selfassembly of E-cadherin directed by cooperative calcium binding, FEBS Lett., 1997, 417, 405-408.

49 S. C. Edington, A. Gonzalez, T. R. Middendorf, D. B. Halling, R. W. Aldrich and C. R. Baiz, Coordination to lanthanide ions distorts binding site conformation in calmodulin, Proc. Natl. Acad. Sci. U. S. A., 2018, 115, 201722042.

50 R. W. Wallace, E. A. Tallant, M. E. Dockter and W. Y. Cheung, Calcium Binding Domains of Calmodulin, J. Biol. Chem., 1982, 257, 1845-1854.

$51 \mathrm{~W}$. Li and R. W. Aldrich, Activation of the SK potassium channel-calmodulin complex by nanomolar concentrations of terbium, Proc. Natl. Acad. Sci. U. S. A., 2009, 106, 1075-1080.

52 F. Hyafil, C. Babinet and F. Jacob, Cell-cell interactions in early embryogenesis: a molecular approach to the role of calcium., Cell, 1981, 26, 447-454.

53 L. Shapiro and W. I. Weis, Structure and biochemistry of cadherins and catenins, Cold Spring Harbor Perspect. Biol., 2009, 1, a003053.

54 E. Heiliger, A. Osmanagic, H. Haase, N. Golenhofen, A. M. Grabrucker, A. Weth and W. Baumgartner, N-cadherinmediated cell adhesion is regulated by extracellular $\mathrm{Zn}^{2+}$, Metallomics, 2015, 7, 355-362.

55 C. Wolf, A. Weth, S. Walcher, C. Lax and W. Baumgartner, Modeling of Zinc Dynamics in the Synaptic Cleft: Implications for Cadherin Mediated Adhesion and Synaptic Plasticity, Front. Mol. Neurosci., 2018, 11, 1-13. 